\title{
ROBERT J. ABBOTT
}

\section{Police Reform in the Russian Province of Iaroslavl, 1856-1876}

In the two decades that followed the Crimean War the local police, always crucial elements of the tsarist system, assumed a new importance. Vested with special responsibility for maintaining law and order and occupying a key position in the bureaucratic hierarchy, they were cast in a major role in carrying out the Great Reforms of Alexander II. The task of fitting the police to assume this role was one of great concern to Russia's leaders and occupied their attention throughout the reign. This essay is a study of police reform in the area of Iaroslavl Province. ${ }^{1}$ It examines the background, nature, and success of government efforts to revitalize an essential branch of the Russian state system.

On the eve of the period of reforms the local police in Iaroslavl as in other Russian provinces were officials of enormous influence. They were the foundation stones of a giant bureaucratic pyramid, for in addition to their special superior-the Ministry of Internal Affairs-a host of ministries, councils, and other government agencies depended on them. Matters of finance and justice, the supervision of industry and commerce, the protection of life and property-all were the concern of the police. Such concentration of power was impressive; but the governor of Iaroslavl was impressed mainly by the heavy burden it involved. ${ }^{2}$ His reaction was understandable, for by the middle of the nineteenth century the volume of police business had reached staggering proportions. A summary of police duties published in $1857^{3}$ ran well

1. The choice of Iaroslav1 Province was prompted by the availability of a considerable amount of material relating to its police during the period under study. An examination of more limited material from other provinces has convinced me that the situation of the Iaroslavl police was in no way unusual or exceptional.

2. Tsentral'nyi gosudarstvennyi istoricheskii arkhiv SSSR (TsGIA SSSR), fond 1281, Sovet Ministerstva Vnutrennikh Del, opis' 6, delo 52, "Po otchetu o sostoianii Iaroslavskoi gubernii za 1856 g.," p. 52.

3. Vasilii Lukin, Pamiatnaia kniga politseiskikh zakonov dlia zemskoi politsii (St. Petersburg, 1857).

This article is the product of research carried out in Leningrad under the sponsorship of the International Research and Exchanges Board. 
over four hundred pages and outlined an area of competence that included virtually every aspect of civil government.

For all the burdens imposed on them, the Iaroslavl police were by no means numerous. In 1857, in a province that covered almost 14,000 square miles and sheltered more than 950,000 people, the Ministry of Internal Affairs had at its disposal only 244 policemen. ${ }^{4}$ By far the greater number-some 194 men-were concentrated in the towns and cities; thus, in terms of numerical strength at least, the municipal police found themselves in a privileged position. In the provincial capital, a city of 29,000 inhabitants, the local chief of police (politsiimeister) commanded a force that included several officers of middle rank (pristavy) and 68 police sergeants and patrolmen. ${ }^{6}$ In the smaller towns the forces were more modest in size, but the ratio of police to people was roughly proportional to that of the capital. In the rural areas, on the other hand, the police could maintain only a token presence. The typical commissioner of rural police (zemskii ispravnik), though he was responsible for an area and population far greater than those of any of the province's cities, was assisted only by a pair of district officers (stanovye pristavy) and one or two other officials. ${ }^{\circ}$ These men were faced with an unenviable task, and demands for an increase in their meager strength formed a constant theme in the yearly reports of the province's governor. ${ }^{7}$

The problem was all the more acute because the police at work in Iaroslavl seem to have been extraordinarily ill qualified. In his 1857 report to the Ministry of Internal Affairs, the provincial governor, Buturlin, admitted as much, remarking that "with very rare exceptions" the men selected for police duty lacked the energy and ability such officials needed. ${ }^{8}$ In a system in which the salaries of police patrolmen often compared unfavorably with those of unskilled laborers this was hardly surprising. ${ }^{\theta}$ But quite apart from low salaries, there were other aspects of police recruitment policies that made such a situation all but unavoidable. In the provincial cities, for example, the tsarist regime had so arranged its requirements as to make the police a haven

4. Materialy sobrannye dlia vysochaishoi uchreshdennoi konmissii o preobrazovanii gubernskikh i uezdnykh uchrezhdenii: Otdel politseiskii (St. Petersburg, 1870-76), part 1, sec. 2, 1870, appendix, pp. 46-47, 118-21 (hereafter MSVUK:OP).

5. The figure of 29,000 inhabitants is drawn from the governor's 1857 report. TsGIA SSSR, f. 1281 , op. 6 , d. 55 , p. 98.

6. The local landlords, of course, provided some assistance to the police. For a discussion of the landlords' police power see Jerome Blum, Lord and Peasant in Russia from the Ninth to the Nineteenth Century (Princeton, 1961; reprint ed., New York, 1964), p. 429.

7. See, for example, TsGIA SSSR, f. 1281, op. 6, d. 52 , 1856, p. 52 ; d. 55, 1857, p. 56.

8. Ibid., op. 6, d. 55 , p. 56.

9. This was the finding of Prince Vasilchikov in an 1858 report. Evgenii Anuchin, Istoricheskii obzor razvitiia administrativno-politseiskikh uchrezhdenii $v$ Rossii (St. Petersburg, 1872), p. 78. 
for those unwilling or unable to perform effectively as soldiers. Under the terms of an 1856 decree the position of police chief was reserved for handicapped veterans, and a law of 1853 made it possible for military commanders to transfer to the municipal police soldiers guilty of insubordination or other misconduct. ${ }^{10}$ In the rural areas where some of the police were elected officials, recruitment policies may well have been worse. ${ }^{11}$ All in all, there seems little reason to doubt that incompetence was every bit as typical as the governor suggested. Added to incompetence, however, was the problem of corruption.

To judge from the yearly reports of Iaroslavl's governors to their superiors, the bribery of police officials was a source of great concern. In their 1860 and 1861 reports, for example, Governors Buturlin and Obolensky took pains to emphasize their diligence in rooting out this abuse-now mentioning the simple dismissal of corrupt personnel, later mentioning the bringing of legal action against them. ${ }^{12}$ For all the suggestions to the contrary, the effects of these measures were probably minimal. A government-sponsored survey of the problem concluded that of the several thousand police who were subordinate to the Ministry of Internal Affairs the number of those who did not regularly accept bribes totaled no more than a few dozen. ${ }^{13}$ Worse still, lacking the opportunities to exact illegal contributions which were open to their superiors, the lower-ranking members of the police often resorted to outright criminal behavior: simple theft, robbery, and armed assault. Thus, in one report the governor could maintain with great conviction that the introduction of additional police into his province had actually increased the level of criminal activity, since the new police were themselves criminal elements. ${ }^{14}$

The remarks of the province's governors reveal another discouraging shortcoming of these men-their total lack of experience..$^{15}$ Baron Haxthausen described the situation in his famous account of his travels through Russia. On the basis of expert testimony he indicated that the stigma associated with police service was. such that those who accepted positions as police tended to enrich themselves as quickly as possible and then leave the system. ${ }^{16}$

10. Vtoroe polnoe sobranie zakonov rossiiskoi imperii (St. Petersburg, 1830-84), vol. 28, no. 27,372; vol. 31 , no. 30,098 , art. 9 (hereafter II PSZ).

11. For a description of the rural police by a most perceptive observer see August Franz von Haxthausen-Abbenburg, The Russian Empire: Its People, Institutions, and Resources, trans. by Robert Faire, 2 vols. (London, 1968), 2:211-12.

12. TsGIA SSSR, f. 1281 , op. 6 , d. 22 , pp. $44-45 ;$ d. 41, p. 32.

13. $M S V U K: O P$, part 1, sec. 2, p. 218.

14. Ibid., p. 325.

15. See the 1857 report of Governor Buturlin. TsGIA SSSR, f. 1281, op. 6, d. 55, p. 56.

16. Haxthausen, Russian Empire, 2:212. 
Table 1. Turnover of Police Personnel, 1855-1858

\begin{tabular}{lc}
\hline \multicolumn{1}{c}{ Level of Service } & $\begin{array}{c}\text { Percentage of Turnover } \\
\text { Years compared: 1858/1855 }\end{array}$ \\
\hline Rural commissioners $(\mathrm{N}=10)$ & 30.0 \\
District officers $(\mathrm{N}=20)$ & 45.0 \\
Police secretaries $(\mathrm{N}=10)$ & 50.0 \\
$\quad$ Total $(\mathrm{N}=40)$ & 42.5 \\
\hline
\end{tabular}

Source: Adres-kalendar: Obshchaia rospis' nachal'stvniushchikh i prochikh dolghnostnykh lits po vsem upravleniiam $v$ imperii i po glavnym upravleniiam $v$ tsarstve pol'skom $i v$ velikom kniazhestve finliandskom (St. Petersburg, 1854, 1857).

Note: The figures do not refer to instances of promotion or demotion within police ranks, but only to instances in which officials' names disappeared from the police roster and were replaced by the names of new officials with no previous record of police service.

In any case, the high turnover of police personnel was an established fact and one which remained a source of concern to the bureaucracy in the years that followed. The concern was well justified, for the figures in table 1, compiled from the 1855 and 1858 rosters of the Iaroslavl police, suggest that-for these levels of police service at least-the high turnover of personnel was a major problem. Forced to rely on police who possessed little ability when they assumed their posts, Iaroslavl's governors apparently were unable to retain them long enough to improve their qualifications. The result was predictable. Overburdened, underqualified, corrupt, and inexperienced, the local police failed to fulfill the duties required of them. Though any of the governors' reports might be cited to illustrate this failure, the 1857 report provides figures that are especially striking. Of 1,546 different items of business referred to the attention of the provincial capital's police in 1857 , some 470 had not been tended to by the end of the year. In Rostov uezd that same year 123 of 230 items went ignored by the police, and throughout the province the picture was similar. ${ }^{17}$

In a number of vital areas of responsibility the breakdown of police services seems for all practical purposes to have been total. The all-important area of internal security is a case in point. Distracted by his other duties and lacking the mounted patrols that would have made it possible to take prompt action against a budding peasant disturbance, the police official was limited to the role of persuader-in-chief in cases of rural riot; and the real task of pacification fell to the military. ${ }^{18}$ As far as crime-fighting services were concerned, the picture was equally bleak. In the five-year period from 1856

17. TsGIA SSSR, f. 1281 , op. 6 , d. 55, p. 69.

18. For illustrations of this problem of police weakness see L. B. Genkin, "Krest'ianskoe dvizhenie v Iaroslavskoi gubernii na rubezhe 1850-1860 kh godov," in Akademiia nauk SSSR, Institut istorii, Revoliutsionnaia situatsiia v Rossii v 1859-1861 gg. (Moscow, 1962), pp. 135, 149. 
to 1861 private losses from theft in Iaroslavl Province totaled almost 1,000,000 rubles, of which the police were able to recover less than $30,000.1^{19}$

In admitting this failure, of course, the governor was also pleading for reform, and as the fifties drew to a close he had every reason to believe that his pleas would be answered. In anticipation of the approaching emancipation the central authorities had begun to display a new interest in the police-an interest that was reflected first in the near deluge of circulars and surveys addressed to the governor's office and later in the formulation and enactment of a series of proposals for reform. The measures enacted were many and were spread out over several years; but when the burst of reforming activity had come to an end, it was clear that there had been a pattern to all this effort and that the government had concentrated on three main objectives.

The first element of the reformers' program was the reduction of police responsibilities to a point that would make the task both manageable and specialized. Step one in this direction was the creation, in June 1860, of a system of magistrates to deal with the pretrial investigation of criminal incidents. ${ }^{20}$ The responsibilities of the police for such matters had been quite extensive and time-consuming. Thus it was widely assumed that their removal would provide welcome relief to a heavily burdened force. To judge from the enthusiastic reception of the reform by the provincial governor, this was precisely the case, for as early as the time of his 1861 report Governor Obolensky was maintaining that the measure was indeed having the desired effect. ${ }^{21}$ By the time the 1863 report was submitted, Obolensky's successor was making the claim that major progress had been achieved and that the police would soon reach the point where they could actually fulfill the duties required of them. ${ }^{22}$

The new governor's prediction was based on the belief that additional measures to relieve the police would soon be forthcoming, and in the light of the information he had received from his superiors this belief was fully justified. Throughout the previous two years tsarist officials had been busy at work on what promised to be the crowning achievements of Alexander II's reform activity: the zemstvo and judicial reforms. Quite aside from their expected contribution to the liberation of Russian society, these were measures

19. TsGIA SSSR, f. 1281 , op. 6, d. 41, "Po otchetu o sostoianii Iaroslavskoi gub. za 1861 g.," p. 21.

20. Three separate pieces of legislation were enacted to create the new officials, define their duties, and explain their relationship to the police. II PSZ, vol. 35, nos. 35,890, $35,891,35,892$. For a closer look at the new officials see B. L. Brazol, "Sledstvennaia chast'," Sudebnye ustavy 20 noiabria $1864 \mathrm{~g}$. za piatdesiat' let, 3 vols. (St. Petersburg. 1914), 2:65-114.

21. TsGIA SSSR, f. 1281, op. 6, d. 41, p. 35.

22. Ibid., d. 27, pp. 64-65. 
Table 2. Volume of Police Business, 1864-1869

\begin{tabular}{lrrrrrr}
\hline District Administration & 1864 & 1865 & 1866 & 1867 & 1868 & 1869 \\
\hline A. Casework & & & & & & \\
Iaroslavl & 496 & 537 & 684 & 486 & 405 & 362 \\
Rybinsk & 272 & 245 & 243 & 185 & 193 & 257 \\
Uglich & 404 & 495 & 440 & 174 & 171 & 139 \\
Myshkin & 112 & 158 & 165 & 127 & 112 & 128 \\
B. Paperwork & & & & & & \\
Iaroslavl & 7,365 & 7,191 & 8,534 & 7,105 & 6,514 & 6,177 \\
Rybinsk & 11,019 & 11,266 & 10,705 & 9,748 & 9,951 & 10,675 \\
Uglich & 15,986 & 16,889 & 17,268 & 14,728 & 14,222 & 14,168 \\
Myshkin & 10,951 & 12,007 & 11,664 & 10,989 & 9,858 & 9,877 \\
C. Casezvork (1867 as a percentage of 1866$)$ & & & & \\
Iaroslavl & & & $100 \%$ & $71 \%$ & & \\
Rybinsk & & & $100 \%$ & $76 \%$ & & \\
Uglich & & $100 \%$ & $40 \%$ & & \\
Myshkin & & $100 \%$ & $77 \%$ & & \\
D. Paperwork (1867 as a percentage of 1866$)$ & & & & \\
Iaroslavl & & $100 \%$ & $83 \%$ & & \\
Rybinsk & & $100 \%$ & $91 \%$ & & \\
Uglich & & $100 \%$ & $85 \%$ & & \\
Myshkin & & $100 \%$ & $94 \%$ & & \\
\hline
\end{tabular}

Source: TsGIA SSSR, f. 1281, op. 7, dd. 27, 32, 34, 37, 38, 59.

that were expected also to liberate the police. In his 1863 report to the Minister of Internal Affairs, Governor Unkovsky gave voice to this expectation, remarking that with the transfer of many duties to the new institutions the volume of police business would be significantly reduced. ${ }^{23}$

By 1864 the zemstvo and judicial reforms had been enacted, but it was 1866 before they were fully operative in Iaroslavl Province. ${ }^{24}$ By 1867 Unkovsky was claiming that his hopes had been fully realized and that the "liberation" of the police was an accomplished fact. Not only had the police burden been lightened, but an element of specialization had been introduced as well, for the removal of so many judicial and administrative duties had freed the police to concentrate on their principal calling- "the protection of social order and security."25 This, at least, was the governor's claim, but what of the reality?

The figures in table 2 would seem to suggest that there was some substance to the governor's boast. Compiled from his yearly reports to the Ministry of Internal Affairs, they offer a picture of the changing volume of police business in four uezd administrations over the course of a six-year period. In part A of the table the figures refer to the number of dela (individ-

23. Ibicl., p. 49.

24. Ibid., op. 7, d. 32, p. 23 ; Sudebnye ustavy, 2:1.

25. TsGIA SSSR, f. 1281, op. 7, d. 37, p. 44. 
ual items of business, or "cases"), and in part B the volume of police paperwork is reported. Since zemstvo and judicial institutions were introduced at the uezd level in 1866, it is the period after that date that should be of special concern here. If indeed the new institutions had contributed to a reduction of police business it could be expected that this would be reflected in the table and that the figures on casework and paperwork would be seen to have declined. ${ }^{28}$ That a reduction of police business was effected by the introduction of the zemstvos and new courts should be clear at a glance. In 1867, or in some instances as early as 1866 , both casework and paperwork began to decline. As parts $C$ and $D$ show, the reduction from 1866 to 1876 was substantial. In most instances--though not in all (witness Rybinsk in A and B, and Iaroslavl in B) - the decline seems either to have continued or to have leveled off in the years that followed.

While trying to reduce police responsibilities, tsarist reformers had also advocated restricting them. In particular it had been suggested (for example, in Unkovsky's 1867 report) that the postreform police should devote the major portion of their time to crime and civil violence. In 1872, at the request of a government commission, an intensive study of the Iaroslavl police was conducted which showed the degree of success achieved. Over the course of a two-month period, government experts assigned each incoming item of police business to one of eight categories. The result was the rather interesting quantitative picture of the police assignment which is summarized in table 3.

The report made it quite clear that the Iaroslavl police were still a far cry from the kind of specialized security force envisaged by Governor Unkovsky. At the district level maintenance of internal security constituted only half the burden of the police. ${ }^{27}$ As much as 12.5 percent of their activity was still concerned with the collection of taxes; as much as 29.6 percent with service as the local representatives of various ministries, commissions, and other agencies of government; and as much as 5.3 percent with the supervision of retired and furloughed military personnel living in their districts. ${ }^{28}$

In the years that followed the submission of the 1872 report, however,

26. Other factors, such as a decrease in population, might also have contributed to a decline in the volume of police business. In the four areas in question, however, the population remained stable during the period under study, and no other complicating factors seem to have been present.

27. This estimate (the approximate total of categories 1, 4, and 6) may be an overly generous one. The responsibilities from category 4 included in the total were related more to the prosecution of criminals than to the prevention and suppression of crime.

28. As the figures in table 3 should make clear, the situation of the commissioner differed considerably from that of the district officer. This difference was accounted for by the greater number of judicial responsibilities (category 4) imposed on the superior officer. This in turn was accounted for by the physical proximity of the commissioner to the local court. 
Table 3. Breakdown of Police Business in 1872 (in percentage)

\begin{tabular}{|c|c|c|c|}
\hline & Category & Commissioners & $\begin{array}{l}\text { District } \\
\text { Officers } \\
\end{array}$ \\
\hline \multicolumn{4}{|c|}{$\begin{array}{l}\text { 1. Prevention and suppression of felonies, misdemeanors, } \\
\text { disorders, epidemics, and livestock diseases; super- } \\
\text { vision of industrial and commercial regulations, pass- } \\
\text { port regulations, and so forth }\end{array}$} \\
\hline 2. & Prevention, extinguishing, and investigation of fires & 0.0 & 0.0 \\
\hline & $\begin{array}{l}\text { Recovery of taxes, obligations, duties, and arrears of } \\
\text { various sorts }\end{array}$ & 9.1 & 12.5 \\
\hline \multicolumn{4}{|c|}{$\begin{array}{l}\text { 4. Execution of judicial decisions, serving subpoenas, } \\
\text { escorting convicts and exiles to places of confinement, } \\
\text { cooperation with investigating magistrates, and so forth } \\
52.5\end{array}$} \\
\hline \multicolumn{4}{|c|}{$\begin{array}{l}\text { 5. Promulgation of decisions of higher instances, execu- } \\
\text { tion of various demands of superior officers and } \\
\text { officials, gathering information for the local adminis- } \\
\text { tration and for higher echelons of government }\end{array}$} \\
\hline 6. & Detection of criminals, recovery of property & 12.9 & 26.5 \\
\hline \multicolumn{4}{|c|}{$\begin{array}{l}\text { 7. Inventory of confiscated property, and auctioning of } \\
\text { same }\end{array}$} \\
\hline & $\begin{array}{l}\text { Registration of furloughed military personnel and } \\
\text { supervision of retired veterans }\end{array}$ & 8.8 & 5.3 \\
\hline & & 99.0 & 98.6 \\
\hline
\end{tabular}

Source: $M S V U K: O P$, part 3, sec. 2, 1872, pp. 4, 66-67.

rather than consolidating the gains of the sixties the tsarist government seems to have retreated from them, enacting measures that further burdened the police and frustrated the policy of specialization. The abolition in 1874 of the arbiters of the peace was a move of this kind, for when these officials were removed from the scene, the major share of their duties fell to the police. ${ }^{20}$ The introduction of new recruitment procedures at the time of the military reform of 1874 also resulted in a significant increase in police business. ${ }^{30}$ By 1876, after still another study of the matter, the government was forced to acknowledge that the responsibilities imposed upon the police were too many and too varied to be fulfilled. ${ }^{31}$ Thus, after a years-long campaign to lighten their load and focus their attention on special tasks, the local police of Iaroslavl Province were still an overburdened, multipurpose force; and insofar as this was true the first element of the reformers' program remained unrealized.

An increase in the strength of the rural police was the second goal. In a province where some 54.7 percent of the population consisted of landlords'

29. V. G. Chernukha, "Krest'ianskii vopros v pravitel'stvennoi politike Rossii (60-70 gody XIX veka)," (Avtoreferat dissertatsii, Leningrad, 1961), pp. 7-8.

30. MSVUK:OP, part 3, sec. 4, 1876, p. 314.

31. Ibid., p. 408. 
serfs, it might well be expected that the period of emancipation would witness major progress toward this target; but as it happened this was not the case. ${ }^{32}$ Lacking the funds to create and support additional police, the Ministry of Internal Affairs was forced to content itself with reshuffling its existing forces. By a decree of December 1862, eight of the province's ten municipal police systems were abolished and their enforcement personnel transferred to the command of the rural commissioners. ${ }^{33}$ Though possibly eliminating jurisdictional conflicts and freeing funds for use elsewhere, this measure did little to strengthen the rural forces, for as foot patrolmen the municipal police could have little influence outside the urban areas. In his 1863 report Governor Unkovsky called attention to this and argued that the size of the rural police was still far from adequate. ${ }^{34} \mathrm{By}$ the time of his 1865 report the governor's criticism had grown sharper still, as he suggested that the effects of the transfer on the provincial towns had been negative ones. ${ }^{35}$ Criticized or not, the transfer remained in force, and aside from the creation of two additional police districts in 1868-a measure of minimal impact-further adjustments in the size of the police were not forthcoming. ${ }^{36}$ Clearly this was an area in which the hopes of the reformers had been frustrated.

The third and final goal of the police program was to improve the quality of the personnel recruited. In June 1860, in the act creating the investigating magistrates, the Ministry of Internal Affairs had expressed special interest in this matter and had outlined the general plan of action to be followed. ${ }^{37}$ By dismissing unsatisfactory officials and then raising police salaries the Ministry hoped to create a completely new force-a force in which men of real competence would be willing to serve, which would have no need for bribes, and which could offer its recruits the prospect of a career of increasingly productive and rewarding service. In short, it would be a force which would attract not the cripple, the criminal, and the transient but the man of ability, honor, and commitment.

The opening years of the sixties had witnessed an attempt to translate this program into action. In December 1862 the salaries of the police had been raised to levels which-in the government's judgment at least-went a long way toward making police service financially attractive and the acceptance of bribes unnecessary. ${ }^{38}$ At the same time the provincial governors were em-

32. For figures on serf population see Genkin, "Krest'ianskoe dvizhenie v Iaroslavskoi gubernii," p. 128.

33. II PSZ, vol. 37 , no. 39,087 .

34. TsGIA SSSR, f. 1281 , op. 6, d. 27 , p. 56.

35. Ibid., op. 7, d. 38, p. 48.

36. Ibid., p. 46.

37. II PSZ, vol. 35 , no. 35,890 , art. 5 .

38. Ibid., vol. 37 , no. 39,087 . 
Table 4. Turnover of Police Personnel, 1865-1868 and 1868-1871

\begin{tabular}{lccc}
\hline \multicolumn{1}{c}{ Level of Service } & Years compared: & \multicolumn{2}{c}{ Percentage of Turnover } \\
& $1868 / 1865$ & $1871 / 1868$ \\
\hline Rural commissioners $(\mathrm{N}=10)$ & 10.0 & 10.0 \\
District officers $(\mathrm{N}=20)$ & 15.0 & 60.0 \\
Police secretaries $(\mathrm{N}=10)$ & 20.0 & 50.0 \\
\multicolumn{1}{c}{ Total $(\mathrm{N}=40)$} & 15.0 & 45.0 \\
\hline
\end{tabular}

Sonrce: Adres-kalendar (St. Petersburg, 1864, 1867, 1870).

Note: See the note to table 1.

powered to dismiss poorly qualified police and to replace them with new officials. In the year that followed, Iaroslavl's governor seems to have taken full advantage of this power, and by the time his annual report was submitted the governor was once again maintaining that the measures enacted by the government were having the desired effect. ${ }^{39}$ Coming as it did from the everenthusiastic Unkovsky, this verdict was somewhat suspect. But valid or not, the favorable evaluation of the reform campaign proved only temporary, for with the passage of a few years the governor's optimistic reports gave way to more sober appraisals.

This was hardly surprising. In 1862 , when the new salary scales were introduced, private observers had judged them adequate but barely so. ${ }^{40}$ And in subsequent years the level of police salaries remained frozen. As early as 1864 , in an otherwise satisfied-sounding report, Iaroslavl's governor had suggested that additional revenues were essential to assure continued progress. ${ }^{41} \mathrm{By}$ 1868 , his suggestion still ignored, he was again bemoaning the slowness and negligence of his police. ${ }^{42}$ He apparently had excellent grounds for complaint, for in a number of respects the problems of the police in these years seem to have been every bit as serious as those they had faced ten years earlier. This apparently was true of the turnover problem, for though the figures in table 4 indicate some success in stabilizing the force between 1865 and 1868, thereafter there seems to have been a return to the prereform situation. Clearly the goal of creating a staff of experienced career officials remained unrealized. As each year went by, the evidence of the government's failure to improve its police grew more and more impressive. By the mid-seventies the body of proof was too great to allow for questioning. The Iaroslavl police were still an incompetent, corrupt, and semi-amateur force; and the attempt to remedy this state of affairs had proved abortive.

39. TsGIA SSSR, f. 1281 , op. 6 , d. 27 , p. 58.

40. Otechestvennyia zapiski, 25 (January 1863): 39.

41. TsGIA SSSR, f. 1281, op. 7, d. 27, p. 34.

42. Ibicl., d. 59, p. 46. 
If the experience of the Iaroslavl police was at all indicative of the general pattern, then the record of police reform was a record of failure. At the outset of its period of reforms the tsarist regime had proposed to reduce the burdens of its police, increase their numbers, and improve their qualifications. By 1876 it was clear that to one extent or another each of these goals remained unrealized. The report of a government commission published in that year acknowledged as much when it admitted that the deficiencies of their personnel, their limited numerical strength, and the volume and variety of their tasks placed the police in an all but impossible situation. ${ }^{43}$ Even as it revealed the problems of the police, however, the report also revealed the enormous degree to which the government still depended on them. The police remained in 1876 what they had been two decades before: foundation stones of the tsarist system. Overburdened, undermanned, incompetent, corrupt, and inexperienced, they still were tremendously important; thus the failure to reform them was equally so. The situation of the local police, discouraging as this study reveals it to have been, was both a symbol and a cause of Russia's political backwardness at the end of the period of reforms.

43. $M S V U K: O P$, part 3, sec. 4, p. 408. 